\title{
Effectiveness of Rinsing Black Tea Compared to Green Tea in Decreasing Oral Bacterial Counts as an Alternative of Caries Prevention
}

\author{
Gema Nazri Yanti ${ }^{1}$, Ranu Putra Armidin ${ }^{2}$ \\ Department of Preventive Dentistry/ Dental Public Health \\ Faculty of Dentistry University of Sumatera Utara \\ Jl.Alumni No.2 Kampus USU Medan, Indonesia \\ gemanazriyanti@yahoo.com
}

\begin{abstract}
Herbal mouthwash is considered as an alternative regimen in maintaining oral hygiene. Tea contains compounds such as catechin and tannin which possess bactericidal and bacteriostatic effect which helps to prevent dental caries. This study was conducted to determine the effectiveness between rinsing with steeping black tea and green tea solution in decreasing the amount of oral bacteria. This is an experimental study with pre and post test controlled group design. The sample were 90 Junior High School students from Swasta Namira School which were then divided into three groups: oral rinsing with steeping black tea (treatment group), oral rinsing with steeping green tea (treatment group) and oral rinsing with aquadest (control group). Saliva collection was carried out before treatment (pre test/ baseline) and after treatment (post test). Treatment group was instructed to rinse $15 \mathrm{ml}$ of steeping black and green tea solution whereas control group were instructed to rinse $15 \mathrm{ml}$ aquadest for 30 seconds and get rid of it. The saliva samples before and after treatment were brought to the microbiology laboratorium for bacteria amount calculation using Total Plate Count (TPC) method. A T-test were used to determine the difference between rinsing with black tea and green tea and Kruskalwalis used to determine the difference between rinsing with steeping black tea, steeping green tea and aquadest towards the mean amount of bacteria before and after treatment. The results showed significant reduction in amount of bacteria in both treatment group where black tea group before treatment $1002.13 \times 10^{3} \pm 784.37 \times 10^{3} \mathrm{CFU} / \mathrm{ml}$ and after treatment $778.06 \times 10^{3} \pm 686.78 \times 10^{3} \mathrm{CFU} / \mathrm{ml}^{3}(\mathbf{p}<0.05)$ and green tea group before treatment $914.40 \times 10^{3} \pm 400.91 \times 10^{3} \mathrm{CFU} / \mathrm{ml}$ and after treatment 636.10 $\times 10^{3} \pm 293.64 \times 10^{3}$ CFUml $(p<0.05)$. The results in control group also showed reduction in amount of bacteria but it was not statistically significant where before treatment 877.3 $\mathrm{x}^{3}{ }^{3} \pm \quad 438.67 \mathrm{x} \quad 1^{3} \mathrm{CFU} / \mathrm{ml}$ and after treatment $782.96 \times 10^{3} \pm 494.55 \times 10^{3}$ CFU/ml $(p>0.05)$. Thus, it can be concluded that rinsing with steeping black tea solution has the same effectiveness in decreasing the total oral bacteria as compared to green tea solution.
\end{abstract}

Keywords: black tea; green tea; caries

\section{INTRODUCTION}

Generally, oral hygiene is one of the indicator in assessing one's oral health. The frequently occurring phenomenon in the community is that lack of attention towards oral hygiene which will cause problems to both the teeth and also oral cavity. The oral cavity is the most complex and favourable breeding places for the microbes to colonize in the human body. Bacteria are the most common microbes found in the human oral cavity [1].

Caries is the consequences of negligence towards importance of oral health. Caries is characterized as the dissolution of the enamel and the root surface (demineralization) by the acid produced from the metabolism of fermented carbohydrates in the diet by the colonizing bacteria on the tooth surface.[2,3] Caries is caused by the teeth (hosts), substrates, time, and microorganisms.[4] Streptococcus mutans are the cariogenic microorganisms that predominate in the oral cavity. In addition, there are also lactobasillus organisms that plays a role in the formation of dental caries.[5] Streptococcus plays a role in the early stages of caries by destroying the outer part of the enamel, meanwhile lactobasillus will be taking over the role of deep caries.4 According to RISKESDAS in 2013, DMF-T scores in Indonesia is 4.6. There are many ways in preventing cariogenic microorganisms, and the usage of herbal mouthwash is one of them.[6]

Medicinal herbs are medicines derived from plants where the plant parts might be from the roots, stems, leaves, tubers, or possibly the entire plant. Plants derived from nature is widely used by the community, especially the people in Indonesia due to the affordable price, user friendly, and the abundance of plants or other materials that can be used as a healthy choice for treatment in Indonesia.[1] The advantages of herbal medicine over modern medicine was producing relatively lesser side effects.Till date, many types of herbs were used and developed as an analgesic, antiinflammatory, anti-bacterial, anti-fungal, and anti-plaque.[2]

According to WHO, $80 \%$ of the world's population still rely on traditional medicine which includes the use of medicines from the plants. Among them is tea due to the perception of people in Indonesia as a daily beverage and it was also the most consumed beverage in the world after water. Tea produced and consumed in the world consists of $78 \%$ black tea, $20 \%$ green tea, less than $2 \%$ oolong tea and the rest are other less popular tea variation.[3]

Tea is one of the plants that contains quite a number polyphenols. The benefits of polyphenols, especially those found in the tea or tea leaves, are tannins and flavonoids such 
as catechin. The catechins contained in the tea leaves are composed of several compounds: C (catechin), EC (epicatechin), EGC (epigalocatechin), and ECG (epigalocatechin).[5] Catechins contained in tea leaves are bactericidal and bacteriostatic. Catechin works by destroying the cytoplasmic membrane of the bacteria as well as causing protein denaturation. [3,5] In addition, the tea also contains fluor.4,6 Fluor possesses antibacterial and antiplaque effects.[4]

The results of Dellon et al's research on the inhibition of black tea, green tea and oolong tea towards the growth of Streptococcus mutans. The results of the study showed that black tea with $3,7833 \pm 0,82744$, green tea with $4,3667 \pm$ 0,6607 , and oolong tea with $4,0889 \pm 0,6061$. From this results, it can be concluded that there is no significant difference in inhibiting Streptococcus mutans among the three groups.[7]

Research conducted by Jalayer et al about the antibacterial activity of green tea and black tea against Streptococcus mutans. The study used five different concentrations ranging from $50 \mathrm{mg} / \mathrm{ml}, 100 \mathrm{mg} / \mathrm{ml}, 200 \mathrm{mg}$ $/ \mathrm{ml}, 300 \mathrm{mg} / \mathrm{ml}$, and $400 \mathrm{mg} / \mathrm{ml}$. From the results showed that green tea were effective at the concentrations of $150 \mathrm{mg} /$ $\mathrm{ml}$ meanwhile black tea was effective at the concentrations of $100 \mathrm{mg} / \mathrm{ml}$. This suggested that black tea was more effective at a lower concentration than the green tea. This study was also supported by the research conducted by Hamdi et al. Their results also showed that black tea reduces bacterial attachment to plaque at concentrations of $1 \mathrm{mg} / \mathrm{ml}$ meanwhile green tea at the concentrations of $1.5 \mathrm{mg} / \mathrm{ml}$.[8]

Nyoman et al conducted a study to analyze the effects of rinsing with black tea towards plaque growth. This study was conducted on 20 respondents which were divided into 2 groups such as group rinsing with chlorhexidine gluconate $0.2 \%$ and the group rinsing with sugarless black tea. An average plaque score before treatment of $6.02 \pm 0.79$ was obtained in the group rinsing with $0.2 \%$ chlorhexidine gluconate meanwhile after treatment was $3.31 \pm 0.58$ whereas in the group rinsing with black sugarless tea before treatment was $6.22 \pm 0.81$ meanwhile after treatment was $1.90 \pm 0.59$. This suggested that black tea is more effective in inhibiting plaque growth $(\mathrm{p}<0.05)$. [6]

The benefits of this research is where by rinsing tea can be an cheap alternative mouthwash, user friendly and free from any chemical compounds which can be used to prevent dental caries.

\section{MATERIALS AND METHODS}

This is a clinical experimental research with pre and post-test group control design. The subjects of this research were 90 students of Namira Medan Private Elementary aged 10-12 years with the inclusion criteria: willingness to be the subject of research and have a minimum decay score of 2 per person. Meanwhile, exclusion criteria are users of fixed orthodontic appliance and prosthesis, suffering from systemic disease and routine user of antiseptic mouth rinses.
Steeping tea solution was made by brewing 2 gr of tea powder (1 tea bag) with $25 \mathrm{ml}$ of water and leave it for 5 minutes to facilitate the escape of catechin from the tea leaves.

Subjects were instructed to fast for 1 hour before the study. Early saliva sampling was performed by the spitting method and then stored in a sterile tube and sealed for the calculation of bacterial counts before treatment (pretest / baseline). Then the subjects were randomly divided into 3 groups such as the treatment group which rinses $15 \mathrm{ml}$ steeping black tea for 30 seconds, treatment group which rinses $15 \mathrm{ml}$ of steeping green tea for 30 seconds and the control group which rinses $15 \mathrm{ml}$ aquadest for 30 seconds. The subjects in all three groups were instructed to rinse and then discarded. Later on, the total saliva of the subjects were immediately stored in a sterile tube and sealed closely to calculate the bacterial count after the treatment (post-test). Sampling of saliva samples was conducted in the field of private primary school Namira Medan. All saliva samples were immediately taken to Microbiology Laboratory of Industrial Chemical Technology Polytechnic (PTKI) Medan for bacterial count using the Total Plate Count (TPC) method.

Data processing was done by using computer program for statistical analysis. The data was analyzed to calculate the difference in mean bacteria count before and after rinsing of steeping black tea, green tea and aquadest using $\mathrm{T}$ test. Kruskalwallis test was also used to calculate the difference in bacterial count between the group rinsing with steeping black tea, green tea and aquadest.

\section{RESULTS}

In the steeping black tea solution group, the average amount of bacterial count before treatment (pre test) was $1002.13 \times 103 \pm 784.37 \times 103 \mathrm{CFU} / \mathrm{ml}$ meanwhile in the steeping green tea solution group was $914.40 \times 103 \pm 400.91 \times 103 \mathrm{CFU} / \mathrm{ml}$ and in the aquadest group was $877.3 \times 103 \pm 438.67 \times 103 \mathrm{CFU} / \mathrm{ml}$. The result of t-test showed no significant difference in the average amount of bacterial count before treatment (pre test) between rinsing group of steeping black tea, green tea solution and aquadest $(\mathrm{p}=0.07)($ Table 1$)$.

TABLE 1. AVERAGE AMOUNT OF BACTERIAL COUNT BEFORE TREATMENT (PRE-TEST) IN STEEPING BLACK TEA, GREEN TEA AND AQUADEST RINSING GROUP

\begin{tabular}{|c|c|c|c|}
\hline Group & $\mathbf{n}$ & $\begin{array}{c}\text { Average amount of } \\
\text { bacterial count before } \\
\text { treatment (pre-test) } \\
\overline{-} \\
(\bar{x} \pm \mathrm{SD})(\mathrm{CFU} / \mathrm{ml})\end{array}$ & $\begin{array}{r}\text { Statistica } \\
\text { Analysis }\end{array}$ \\
\hline $\begin{array}{l}\text { Rinsing steeping } \\
\text { black tea solution }\end{array}$ & 30 & $1002.13 \times 103 \pm 784.37 \times 103$ & \multirow{3}{*}{$\mathrm{p}=0.07$} \\
\hline $\begin{array}{l}\text { Rinsing steeping } \\
\text { green tea solution }\end{array}$ & 30 & $914.40 \times 103 \pm 400.91 \times 103$ & \\
\hline Rinsing aquadest & 30 & $877.3 \times 103 \pm 438.67 \times 103$ & \\
\hline
\end{tabular}

In the steeping black tea solution group, the average amount of bacterial count before treatment (pre-test) was $1002.13 \times 103 \pm 784.37 \times 103 \mathrm{CFU} / \mathrm{ml}$ whereas after treatment (post-test) was $778.06 \times 103 \pm 686.78 \times 103 \mathrm{CFU} / \mathrm{ml}$. In the 
steeping green tea group, the average amount of bacterial count was $914.40 \times 103 \pm 400.91 \times 103 \mathrm{CFU} / \mathrm{ml}$ whereas after treatment (post-test) was $636.10 \times 103 \pm 293.64 \times 103 \mathrm{CFU} / \mathrm{ml}$. Meanwhile in the aquadest group, the average amount of bacterial count before treatment (pre-test) was $877.3 \times 103 \pm$ 438.67x103 CFU / ml whereas after treatment (post-test) was $782.96 \times 103 \pm 494.55 \times 103 \mathrm{CFU} / \mathrm{ml}$. The result of t-test showed that there was a significant decrease in bacterial count in steeping black tea and green tea solution group $(\mathrm{p}<0,05)$ whereas no significant decrease in the aquadest rinsing group. $(\mathrm{p}=0.17)$. (Table 2$)$.

TABLE 2. AVERAGE AMOUNT OF BACTERIAL COUNT BEFORE TREATMENT (PRE TEST) AND AFTER TREATMENT (POST TEST) IN STEEPING BLACK TEA, GREEN TEA AND AQUADEST RINSING GROUP.

\begin{tabular}{|c|c|c|c|c|}
\hline \multirow{2}{*}{ Group } & \multirow{2}{*}{$\mathbf{n}$} & $\begin{array}{c}\text { Average amount of bacterial count } \\
(\bar{x} \pm \text { SD) }\end{array}$ & \multirow{2}{*}{$\begin{array}{c}\text { Statistical } \\
\text { Analysis }\end{array}$} \\
\cline { 3 - 4 } & & Before & After & \\
\hline $\begin{array}{c}\text { Rinsing } \\
\text { steeping } \\
\text { black tea } \\
\text { solution }\end{array}$ & 30 & $\begin{array}{c}1002.13 \times 103 \pm \\
784.37 \times 103\end{array}$ & $\begin{array}{c}778.06 \times 103 \pm \\
686.78 \times 103\end{array}$ & $\mathrm{p}=0.002$ \\
\hline $\begin{array}{c}\text { Rinsing } \\
\text { steeping } \\
\text { green tea } \\
\text { solution }\end{array}$ & 30 & $\begin{array}{c}914.40 \times 103 \pm \\
400.91 \times 103\end{array}$ & $\begin{array}{c}636.10 \times 103 \pm \\
293.64 \times 103\end{array}$ & $\mathrm{p}=0.003$ \\
\hline $\begin{array}{c}\text { Rinsing } \\
\text { aquadest }\end{array}$ & 30 & $\begin{array}{c}877.3 \times 103 \\
\pm 438.67 \times 103\end{array}$ & $\begin{array}{c}782.96 \times 103 \pm \\
494.55 \times 103\end{array}$ & $\mathrm{p}=0.17$ \\
\hline
\end{tabular}

The difference in the bacterial count of pre-treatment and post-treatment in the steeping black tea rinsing group was $224.07 \times 103 \pm 353.51 \times 103 \mathrm{CFU} / \mathrm{ml}$ whereas the difference in the bacterial count before treatment (pre-test) and after treatment (post-test) in steeping green tea rinsing group was $278.3 \times 103 \pm 357.62 \times 103 \mathrm{CFU} / \mathrm{ml}$. The difference in the average amount of bacterial count between the groups before treatment (pre-test) and after treatment (post-test) was $94.34 \times 103 \pm 411.51 \times 103 \mathrm{CFU} / \mathrm{ml}$. The results showed that there was a significant difference between the rinsing group of steeping black tea, green tea and aquadest solution $(\mathrm{p}=0.004)$ (Table 3).

TABLE 3. DIFFERENCE IN BACTERIA COUNT BEFORE (PRE TEST) AND AFTER TREATMENT (POST TEST) IN STEEPING BLACK TEA, GREEN TEA AND AQUADEST RINSING GROUP.

\begin{tabular}{|c|c|c|c|}
\hline Group & $\mathrm{n}$ & $\begin{array}{c}\text { Difference in bacteria } \\
\text { count } \\
(\bar{x} \pm \mathrm{SD})(\mathrm{CFU} / \mathrm{ml})\end{array}$ & Statistical Analysis \\
\hline $\begin{array}{c}\text { Rinsing steeping } \\
\text { black tea } \\
\text { solution }\end{array}$ & 30 & $\begin{array}{r}224.07 \times 103 \pm 353.51 \\
\mathrm{x} 103\end{array}$ & \\
\hline $\begin{array}{c}\text { Rinsing steeping } \\
\text { green tea } \\
\text { solution }\end{array}$ & 30 & $\begin{array}{r}278.3 \times 103 \pm 357.62 \\
\mathrm{x} 103\end{array}$ & $\mathrm{P}=0.004$ \\
\hline $\begin{array}{c}\text { Rinsing } \\
\text { aquadest }\end{array}$ & 30 & $\begin{array}{c}94.34 \times 103 \pm \\
411.51 \times 103\end{array}$ & \\
\hline
\end{tabular}

\section{DISCUSSION}

The result of statistical analysison bacterial count before treatment (pre-test) showed no significant difference between the steeping black tea rinsing group with $1002.13 \times 103 \pm 784.37 \times 103 \mathrm{CFU} / \mathrm{ml}$,steeping green tea rinsing group with $914.40 \times 103 \pm 400.91 \times 103 \mathrm{CFU} / \mathrm{ml}$ and aquades solution rinsing group with $877.3 \times 103 \pm 438.67 \times 103$ CFU / $\mathrm{ml}(\mathrm{p}=0.07)$. This is mainly due to the selection of subjects based on inclusion and exclusion criteria such as a minimum of two decay scores per person, without fixed or removable orthodontic appliance, without prosthesis, without systemic disease, and no regular use of antiseptic mouth rinse therefore the oral condition of each subjects possess minor differences among the three groups.

There was a significant decrease in the bacterial count in the steeping black tea and green tea solution rinsing groups ( $\mathrm{p}<0.05)$, whereas there was no significant decrease in the bacterial count in the aquadest rinsing group $(p=0.17)$. This happened because the steeping black tea and green tea contains catechin. Catechins contained in the tea leaves are bactericidal and bacteriostatic. Catechin works by inhibiting the activity of glucosyltransferase enzymes produced by Sterptococcus mutans bacteria. The glucosyltransferase enzyme will convert sucrose to glucan which inhibit the formation of carbohydrate that is easily fermented (maltose) by bacteria hence bacterial growth will be inhibited and also decrease in acid production by bacteria. $[9,10]$ Besides that, black tea also contains tannin which have the ability to inactivate the adhesion of microbial cells (molecules attached to host cells) present on the cell surface and the enzymes attached to cell membranes or the cell wall polypeptides.[10] These results are consistent with the Jalayer et al study which examined the antibacterial activity of green tea and black tea against Streptococcus mutans bacteria. The results of Jalayer et al's study showed that black tea was more effective than green tea at lower concentrations. Whereas in the aquadest rinsing group, a decrease in the bacterial count may be due to mechanical effects of rinsing but not because of the chemical effects possessed in the black tea and green tea therefore the amount of bacteria that is reduced is not significant.[11]

This result is consistent with Dellon et al's research on inhibition of black tea, green tea and oolong tea towards the growth of Streptococcus mutans. In this study found that black tea with $3,7833 \pm 0,82744$, green tea with $4,3667 \pm 0,6607$, and oolong tea with $4,0889 \pm 0,6061$. From this results, it can be concluded that there was no significant difference among the three groups in inhibiting Streptococcus mutans.[7] This results indicate that the steeping black tea is as effective as the steeping green tea. This may be due to both the leaves of black tea and green tea possess an antibacterial trait that can cause a decrease in the bacterial count. Black tea and green tea leaves both contain catechins, but the leaves of black tea undergo an enzymatic oxidation process which causes the catechin to turn into theaflavin and thearubigin. Theaflavin in the black tea plays a role in the inhibition of salivary amylases and bacteria by inhibiting the fermentation process of sugars that can produce acids. The amount of theaflavin in the black tea is 95 
times more than the green tea, meanwhile thearubigin is 45 times more than that in green tea.[12]

These results also showed that the results of this study were more effective due to the content of black tea and green tea which were more likely to reduce the bacterial count than the mechanical effects of rinsing that produced lesser effects in decreasing the bacterial count.

\section{ACKNOWLEDGEMENT}

This research was funded by the research foundation in the University of Sumatera Utara with the following contract number of 235/UN5.2.3.1/ PPM/KP-TALENTA USU/2017.

\section{REFERENCES}

[1]. Lamont RJ, Jenkinson HF. Oral microbiology at a glance. Oxford: Wiley-Blackwell, 2010: 3,9.

[2]. Marsh PD, Martin MV. Oral microbiology. Fifth edition. London: Elsevier, 2009:2.

[3]. Pintauli S, Hamada T. Menuju gigi \& mulut sehat. Medan: USU Press, 2012:4.

[4]. Prasetya RC. Perbandingan jumlah koloni bakteri saliva pada anak anak karies dan non karies setelah mengkonsumsi minuman berkarbonisasi. Indonesian Dentistry 2008; 15(1): 66.

[5]. Akinyele BJ, Oladejo BO, Akinyemi AL, Ezem LO. Comparative study of the antibacterial effect of mouth washes and Vernonia amygdalina (del.) on some tooth decay causing bacteria. British Microbiology Research 2014; 4(7): 750.

[6]. Departemen kesehatan. Riset kesehatan dasar 2013:119.

[7]. Wijaya D. Daya hambat teh hitam, teh hijau dan teh oolong terhadap pertumbuhan Streptococcus mutans. Jurnal Kesehatan Gigi Makasar 2013; 5(1):6.

[8]. Dewoto HR. Pengembangan obat tradisional Indonesia menjadi fitifarmaka. Majalah Kedokteran Indonesia 2007;57(7):205.

[9]. Suma FP, Dewi N, Adhani R. Efektivitas seduhan teh hitam (Camellia sinensis) dalam penurunan indeks plak gigi. J of Dentino Dentistry. 2016;2(1):186-190.

[10]. Wahyuni A, Dewi N, Budiarti LY. Uji efektivitas antibakteri sediaan tunggal dibandingkan kombinasi seduhan daun the hijau (Camellia sinensis) dan madu. J of Dentino 2016;1(2):4-5.

[11]. Naderi NJ, Niakan M, Kharazi M.J, Zardi S. Antibacterial activity of Iranian green and black tea on Streptococcus mutans: an in vitro study. 2011;2(8);55-59.

[12]. Liwang F. Manfaat konsumsi teh hitam sebagai upaya preventif penyakit jantung koroner akibat arterosklerosis di Indonesia. Jurnal UI Untuk Bangsa Seri Kesehatan, Sains, dan Teknologi 2010;1:31-4. 